\title{
EFEKTIVITAS PENGGUNAAN MEDIA VIDEO PEMBELAJARAN PADA PEMBELAJARAN GEOGRAFI DI SMAN 1 RASAU JAYA
}

\author{
Tanti Anggraini, Maria Ulfah, Agus Sugiarto \\ Program Studi Pendidikan Geografi FKIP Untan Pontianak \\ Email: emailpenulis@untan.com
}

\begin{abstract}
This study aims to determine the effectiveness of using instructional video media in improving student learning outcomes. This type of research is experimental research with a quasi-experimental form. The data was collected by giving a test, in the form of a multiple choice written test, totaling 50 questions to the students of class XI IPS 2 as the experimental class and class XI IPS 3 as the control class of SMAN 1 Rasau Jaya. Based on the results of the average post-test score of the experimental class of 62.83, while the post-test score of the control class was 53.66. From this data, it can be seen that there are differences in student learning outcomes in the experimental class and the control class. Judging from the different test results with tcount> table $(3.074>2.048)$ with a value of $0.003<0.05$, which means that there are differences in student learning outcomes. This shows that the effectiveness of using video media can improve student learning outcomes. This is also evidenced by the result of an effect size of 0.8 with criteria classified as high.
\end{abstract}

Keywords: Effectiveness, Video Media, Learning Outcomes

\section{PENDAHULUAN}

Pendidikan merupakan suatu usaha yang sengaja diberikan kepada seseorang untuk mengembangkan bakat, potensi dan keterampilan yang dimiliki dengan tujuan yang telah ditetapkan. Adanya pendidikan bertujuan untuk perubahan perilaku yang diinginkan, terjadi setelah seseorang melakukan proses kegiatan belajar. Menurut Ahmadi Rulam (201:49) tujuan pendidikan adalah mengembangkan segala potensi bawaan manusia secara integral, simultan, dan berkelanjutan agar manusia mampu melaksanakan tugas dan kewajiban dalam kehidupan guna mencapai kebahagian di masa sekarang dan di masa mendatang.

Pelaksanaan pembelajaran geografi dikelas harus mampu memberikan pengalaman belajar yang menarik agar mencapai hasil belajar sesuai dengan kompetensi dasar dan tujuan pembelajaran. Pembelajaran geografi terletak pada bagaimana strategi guru menyampaikan materi, dengan adanya strategi maka guru mampu memberikan suasana belajar yang berbeda sehingga membangkitkan semangat belajar pada siswa. Penggunaan media pembelajaran yang tepat akan memberikan pengaruh terhadap hasil belajar siswa, kurikulum 2013 mengharapkan siswa aktif dalam pembelajaran baik dalam budaya bertanya, mengkomunikasikan dan berpikir kritis, guru sebagai fasilitator dalam pembelajaran hal ini guna meningkatkan mutu siswa.

Media video dapat menampilkan fenomenafenomena geosfer yang susah diamati bahkan fenomena yang tidak ada di lingkungan sehingga media video dapat memvisualisasikan materimateri geografi terutama materi pada kelas XI. Pembelajaran menggunakan media video memberikan pengalaman yang menarik karena terdapat unsur-unsur gambar, bergerak dan suara yang diaplikasikan pada materi ketahanan pangan, bahan industri, dan energi terbarukan maka dari itu media video dibutuhkan agar proses 
pembelajaran tidak monoton serta mempengaruhi hasil belajar siswa.

Berdasarkan hasil wawancara dengan guru mata pelajaran geografi Bapak M Nurdin Hamid, S.Pd, dapat diketahui bahwa nilai rata-rata ulangan harian materi ketahanan pangan, bahan industri, dan energi terbarukan berada di bawah KKM. Nilai yang masih dibawah rata-rata menunjukkan bahwa terdapat masalah dalam proses pembelajaran. Masalah tersebut adalah proses pembelajaran yang hanya menggunakan media cetak dengan metode konvensional. Proses pembelajaran guru menggunakan media cetak yaitu buku paket dan metode konvensional yaitu ceramah, media dan metode ini lebih gampang untuk dilakukan. Guru jarang menggunakan media pembelajaran dikarenakan kurangnya sumber media yang ada di sekolah. Selain itu, guru juga belum pernah menggunakan media video dalam proses pembelajaran ditambah lagi materi ketahanan pangan, bahan industri, dan energi terbarukan merupakan materi yang lebih banyak menekankan pada pemahaman siswa yang tidak hanya dapat disampaikan dengan media cetak saja. Hal ini membuat siswa berada pada suasana belajar yang kurang kondusif seperti mengantuk sehingga kurangnya interaksi antara siswa dengan siswa, maupun siswa dengan guru akibatnya terjadi kondisi belajar yang tidak menarik di dalam kelas.

Berdasarkan permasalahan yang ada, dapat diidentifikasi bahwa terdapat beberapa masalah dalam proses pembelajaran geografi. Penelitian ini dilakukan untuk berkontribusi dalam proses pembelajaran sehingga membuktikan pentingnya penggunaan media video. Adapun materi ketahanan pangan, bahan industri, dan energi terbarukan dipilih karena materi ini cocok diterapkan pada media video. Media gambar pada buku teks dengan menggunakan metode konvensional pada proses pembelajaran tidak cukup baik untuk membuat siswa memahami materi. Penerapan materi ketahanan pangan, bahan industri, dan energi terbarukan diperlukan kerja sama antara siswa dengan siswa maupun siswa dengan guru sehingga tercipta suasana belajar yang kondusif hingga menyenangkan, dan dapat melibatkan siswa dengan berperan aktif dalam proses pembelajaran di dalam kelas.

Media video memberikan pengalaman belajar yang menarik sehingga mampu mempengaruhi hasil belajar siswa menjadi lebih baik. Oleh karena itu, untuk membuktikan teori- teori diatas maka penulis tertarik untuk melakukan penelitian eksperimen yang berjudul "Efektivitas Penggunaan Media Video Pembelajaran Pada Pembelajaran Geografi Di SMAN 1 Rasau Jaya". Harapan penggunaan media video pembelajaran ini dapat meningkatkan hasil belajar siswa khususnya mata pelajaran geografi materi ketahanan pangan, bahan industri, dan energi terbarukan di kelas XI IPS Sekolah Menengah Atas Negeri 1 Rasau Jaya sehingga dapat mencapai nilai sesuai dengan kriteria ketuntasan minimal (KKM).

Berdasarkan hasil wawancara dan pengamatan, maka identifikasi masalah penelitian ini antara lain: hasil belajar siswa pada pembelajaran geografi dengan menggunakan media video pembelajaran di kelas XI IPS SMAN 1 Rasau Jaya, hasil belajar siswa pada pembelajaran geografi dengan menggunakan media gambar pada buku teks di kelas XI IPS SMAN 1 Rasau Jaya, terdapat perbedaan hasil belajar siswa pada pembelajaran geografi yang menggunakan media gambar pada buku paket dengan menggunakan media video pembelajaran di kelas XI IPS SMAN 1 Rasau Jaya, seberapa besar efektivitas penggunaan media video pembelajaran terhadap hasil belajar siswa pada pembelajaran geografi di kelas XI IPS Sekolah Menengah Atas Negeri 1 Rasau Jaya.

\section{METODE PENELITIAN}

Jenis penelitian yang dipilih pada penelitian ini merupakan penelitian kuantitatif. Sedangkan metode penelitian dalam penelitian ini menggunakan metode eksperimen, metode eksperimen yang digunakan untuk mencari pengaruh yang diberikan terhadap variabel penelitian dengan mengontrol variabel yang lain. Bentuk penelitian yang digunakan adalah Quasi Eksperimen. Adapun penelitian eksperimen Quasi-Eksperimental ini, peneliti menggunakan bentuk Nonequivalent Control Group Design yaitu dengan menggunakan tes pengetahuan awal dan tes pengetahuan akhir pada siswa. Adapun rancangan Nonequivalent Control Group Design (Sugiyono, 2012: 116) yaitu sebagai berikut

Tabel 1 Rancangan Nonequivalent Control Group Design

\begin{tabular}{lll}
\hline $\mathrm{O}_{1}$ & $\mathrm{X}_{1}$ & $\mathrm{O}_{2}$ \\
\hline $\mathrm{O}_{3}$ & $\mathrm{X}_{2}$ & $\mathrm{O}_{4}$ \\
\hline
\end{tabular}


Keterangan

$\mathrm{O}_{1}$ : Hasil tes pengetahuan awal kelas kontrol

$\mathrm{O}_{3}$ : Hasil tes pengetahuan awal kelas eksperimen

$\mathrm{O}_{2}$ : Hasil tes pengetahuan akhir kelas konrol

$\mathrm{O}_{4}$ : Hasil tes pengetahuan akhir eksperimen

$\mathrm{X}_{1}$ :Perlakuan pada kelas eksperimen dengan menggunakan media gambar yang terdapat di buku teks

$\mathrm{X}_{2}$ :Perlakuan pada kelas eksperimen dengan menggunakan media video

Menetapkan kelas kontrol dan kelas eksperimen dengan cara teknik Nonprobality Sampling yaitu Purposive Sampling. Setelah dilakukan musyawarah bersama guru mata pelajaran geografi tersebut maka dapat disimpulkan bahwa kelas XI IPS 2 dijadikan sebagai kelas eksperimen dan kelas XI IPS 3 dijadikan sebagai kelas kontrol.

\section{Tahap-tahap Penelitian}

Berdasarkan prosedur penelitian, penelitian ini disusun dengan beberapa tahap penelitian. Adapun tahap-tahap dalam melaksanakan penelitian yaitu :

\section{Tahap Persiapan}

1) Melakukan validitas soal dengan guru geografi kelas XI IPS SMAN 1 Rasau Jaya.

2) Melakukan uji validitas soal kepada siswa kelas XII IPS di SMAN 2 Sungai Raya, dengan jumlah soal sebanyak 50, hasil soal yang valid berjumlah 43 soal.

3) Melakukan tes pengetahuan awal kepada siswa kelas XI IPS 2 dan XI IPS 3 untuk menetukan kelas kontrol dan kelas eksperimen.

4) Menghitung rata-rata hasil tes pengetahuan awal kelas XI IPS 2 dan XI IPS 3. Hasil analisis tes pengetahuan awal kelas XI

\section{Tahap Pelaksanaan}

1) Melakukan kegiatan pembelajaran dengan memberikan perlakuan di kelas eksperimen menggunakan media video pembelajaran.

2) Melakukan kegiatan pembelajaran dengan memberikan perlakuan di kelas kontrol menggunakan media cetak.

3) Memberikan tes akhir pada kelas eksperimen

4) Memberikan tes akhir pada kelas kontrol

\section{Tahap akhir}

1) Menskor hasil tes akhir. Nilai rata-rata tes pengetahuan akhir kelas eksperimen yaitu
62,84 dan nilai rata-rata kelas kontrol yaitu 53,67 dengan menggunakan SPSS 25.

2) Menghitung uji normalitas data hasil tes akhir kelas eksperimen dan kelas kontrol dengan menggunakan SPSS 25 yaitu kolmogorovSmirnov Test data berdistribusi normal dengan hasil diperoleh pada kelas eksperimen 0,05 dan pada kelas kontrol 0,20.

3) Menghitung homogenitas varians data tes akhir kelas eksperimen dan kelas kontrol menggunakan SPSS 25 yaitu One Way Annova dengan signifikansi 0,70.

4) Menghitung uji t menggunakkan SPSS 25 yaitu Independent Sample T-Test diperoleh 0,003. Maka dapat disimpukan bahwa $\mathrm{H}_{0}$ ditolak dan $\mathrm{H}_{\mathrm{a}}$ terima. Artinya terdapat perbedaan yang signifikan antara kelas kontrol dan kelas eksperimen.

5) Menghitung effect size yaitu dengan hasil 0,8 artinya penggunaan penggunaan media video pembelajaran memberika efektivitas yang tinggi terhadap hasil belajar siswa pada materi ketahanan pangan.

\section{Populasi dan Sampel \\ Populasi}

Menurut Sugiyono (2017:80) "populasi adalah wilayah generalisasi yang terdiri atas obyek atau subyek yang mempunyai kualitas dan karakteristik tertentu yang ditetapkan oleh peneliti untuk dipelajari dan kemudian ditarik kesimpulannya" Objek yang memiliki karakteristik sehingga ditetapkan untuk dipelajari dan ditarik kesimpulan. Menurut Musfiqqon (2012:89) "populasi adalah totalitas objek penelitian yang dapat berupa manusia, hewan, tumbuhan, dan benda yang mempunyai kesamaan sifat". Terdapat objek penelitian yang berupa semua makhluk hidup dan mati yang mempunyai kesamaan sifat.

Menurut Trijono Rachmat (2015:30) "populasi adalah keseluruhan unit yang menjadi objek kegiatan statistik baik yang berupa instansi pemerintah, lembaga, organisasi, orang, benda maupun objek lainnya". Populasi dapat didefinisikan sebagai keseluruhan unit yang dijadikan objek oleh lembaga-lembaga. Jadi populasi pada penelitian ini adalah seluruh data atau objek yang digunakan dalam penelitian. Sehubungan dengan penelitian, maka populasi materi ketahanan pangan, bahan industri, dan energi terbarukan pada penelitian ini adalah 
seluruh kelas XI IPS Sekolah Menengah Atas Negeri 1 Rasau Jaya.

Tabel 2 Populasi Penelitian

\begin{tabular}{lcc}
\hline No & Kelas & Jumlah Siswa \\
\hline 1. & XI IPS 1 & 30 Orang \\
\hline 2. & XI IPS 2 & 31 Orang \\
\hline 3. & XI IPS 3 & 29 Orang \\
\hline 4 & XI IPS 4 & 31 Orang \\
\hline
\end{tabular}

\section{Sampel}

Menurut Sugiyono (2017:80), "sampel adalah bagian dari jumlah dan karakteristik yang dimiliki oleh populasi tersebut". Adanya bagian dari jumlah dan karakteristik dari populasi. Menurut Trijono Rachmat (2015:31) "sampel adalah sebagian unit populasi yang menjadi objek penelitian untuk memperkirakan karakteristik suatu populasi". Sebagian unit populasi yang menjadi objek penelitian untuk memperkirakan karakteristik. Menurut Riyanto dalam (Musfiqon, 2012:90), "sampel adalah bagian dari populasi”.

Jadi sampel pada penelitian ini adalah sebagian dari populasi yang menjadi objek penelitian. Sehubungan dengan penelitian, maka sampel dalam penelitian ini dipilih dua kelas XI IPS dari empat kelas yang belum mempelajari materi ketahanan pangan, bahan industri, dan energi terbarukan. Sehingga sampel yang digunakan adalah sampel kelas. Pemilihan kelas yang akan dijadikan sampel penelitian dilakukan dengan pengambilan secara acak. Kedua kelas tersebut diberikan tes awal untuk menentukan bahwa kelas tersebut memiliki kemampuan yang sama.

Teknik pengambilan sampel yang digunakan dalam penelitian ini adalah teknik sampling purposive. Sampling Purposive adalah teknik pengambilan sampel dengan pertimbangan tertentu (Sugiyono, 2017:85). Teknik ini dipilih karena berdasarkan beberapa pertimbangan yang dilakukan oleh peneliti sebelum menentukan sampel.

Sampel dalam penelitian ini adalah kelas XI IPS 2 sebagai kelas eksperimen, sedangkan kelas XI IPS 3 sebagai kelas kontrol karena pertimbangan yang di ambil adalah rekomendasi dari dari guru pengampu geografi di sekolah.
Dengan melihat kemampuan nilai rata-rata dari kelas XI IPS 2 dan XI IPS 3 sama dan mempertimbangkan waktu penelitian pada kelas eksperimen dan kelas kelas kontrol 1 pertemuan selama 2x45 menit. Sedangkan pada kelas yang lainnya jam pelajaran dalam 1 pertemuan hanya 1x45 menit sehingga kurang kondusif jika dipilih sebagai kelas eksperimen maupun kelas kontrol.

\section{HASIL PENELITIAN DAN PEMBAHASAN Hasil}

Penelitian ini dilaksanakan pada kelas XI IPS 2 sebagai kelas eksperimen, sedangkan kelas kontrol dilaksanakan pada kelas XI IPS 3. Pada saat penelitian kelas eksperimen menggunakan media video pembelajaran. Berbeda dengan kelas kontrol, media yang digunakan adalah media gambar yang terdapat dibuku paket.

Tabel 3 Nilai Hasil Belajar Siswa Kelas Eksperimen dan Kelas Kontrol

\begin{tabular}{ccc}
\hline Kelas & Jumlah & $\begin{array}{c}\text { Rata- } \\
\text { rata }\end{array}$ \\
\hline Eksperimen & 1948 & 62,83 \\
\hline Kontrol & 1610 & 53,66 \\
\hline
\end{tabular}

Berdasarkan data tabel rata-rata nilai hasil belajar siswa kelas eksperimen yang menggunakan media video pembelajaran sebesar 62,83 , sedangkan nilai rata-rata tes kelas kontrol yang menggunakan media gambar yang terdapat dibuku paket adalah 53,66. Dari pemaparan tersebut diketahui selisih antara rata-rata tes akhir kelas eksperimen dan nilai rata-rata tes akhir kontrol adalah 9,17. Berdasarkan tabel nilai hasil belajar siswa kelas eksperimen dan kelas kontrol di atas dapat dilihat pada grafik di bawah ini.

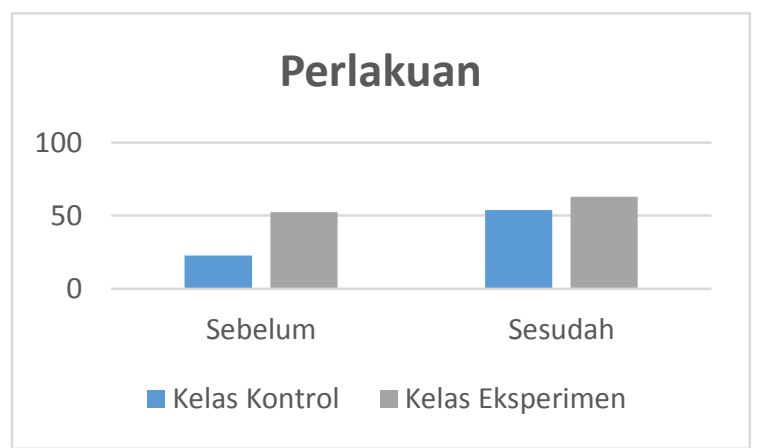

Gambar 1 Grafik Hasil Belajar Siswa 
Berdasarkan grafik di atas dapat diketahui bahwa hasil belajar siswa kelas eksperimen dan kelas kontrol memiliki perbedaan. Pada kelas eksperimen jumlah nilai yang diperoleh siswa adalah 1.948, sedangkan pada kelas kontrol jumlah nilai yang diperoleh siswa adalah 1.610.

\section{Pembahasan}

1. Hasil belajar siswa yang menggunakan media video pembelajaran

Pembelajaran pada kelas eksperimen yang menggunakan media video pembelajaran berlangsung secara baik. Hal ini dikarenakan penggunaan media video pembelajaran lebih bervariasi dan menitikberatkan pemahaman secara visual. Proses pembelajaran yang menggunakan media video pembelajaran mampu mengkaitkan materi ketahanan pangan berdasarkan daerah masing-masing. Pembelajaran menggunakan media video membuat hasil belajar siswa lebih baik dibandingkan dengan pembelajaran menggunakan media gambar yang terdapat dibuku paket. Hal ini sejalan dengan penelitian yang dilakukan oleh Buyung Iman Taka (2016) yang meneliti tentang efektifitas penggunaan media video pada pembelajaran siswa kelas XI Teknik Otomotif SMK Palapa Semarang. Dalam penelitian tersebut hasil belajar siswa kelas eksperimen yang diajar menggunakan media video yang semula 62,357 meningkat menjadi 84,57. Arsyad (2014: 50) mengatakan bahwa" kemampuan film dan video melukiskan gambar hidup dan suara memberikan daya tarik tersendiri, mereka dapat menyajikan informasi, memaparkan proses, menjelaskan konsepkonsep yang rumit, mengajarkan keterampilan, menyingkat atau memperpanjang waktu dan mempengaruhi sikap". Berdasarkan pemaparan tersebut dapat disimpulkan bahwa media video lebih efektif dan interaktif dalam memotivasi siswa untuk fokus pada pembelajaran sehingga menimbulkan rasa ingin tahu terhadap materi yang disajikan guru.

Menurut Slameto (2015:54), faktor yang mempengaruhi hasil belajar ada dua golongan yaitu faktor intern; faktor yang ada dalam diri individu yang sedang belajar dan faktor ekstren; faktor yang ada diluar individu. Media video termasuk faktor ekstren yang dapat mempengaruhi hasil belajar siswa. Dengan menggunakan media video, pembelajaran di dalam kelas dapat di demonstrasikan secara nyata dan informasiinformasi penting dapat jelas tersampaikan kepada siswa.

2. Hasil belajar siswa yang menggunakan media gambar yang terdapat dibuku paket

Proses pembelajaran di kelas kontrol yang menggunakan media gambar yang terdapat di buku paket berlangsung secara baik. Namun, siswa kurang berperan aktif dalam mengikuti proses pembelajaran. Hal tersebut dikarenakan pembelajaran yang menggunakan media gambar yang terdapat di buku paket kurang bervariasi sehingga membuat siswa bosan bahkan ada beberapa siswa yang tertidur saat pembelajaran berlangsung. Menurut Hamdani (2011:251) "media gambar memiliki 3 kelemahan yakni hanya menekankan pada presepsi indera mata saja, benda yang terlalu kompleks kurang efektif untuk kegiatan pembelajaran, ukurannya sangat terbatas untuk kelompok besar". Penelitian yang dilakukan oleh Woro Mahardikaning Pratiwi (2019) tentang efektivitas penggunaan media audio visual dengan media gambar terhadap hasil belajar ips siswa SDN Semarang membuktikan bahwa hasil belajar menggunakan media gambar lebih rendah dengan persentase $73,6 \%$ dibanding media video 78,9\%. Dengan demikian dapat disimpulkan bahwa media gambar kurang efektif untuk diaplikasikan sebagai media dalam pembelajaran. Sementara materi ketahanan pangan, bahan industri dan energi terbarukan membutuhkan penjabaran yang konkrit karena berkaitan dengan kehidupan sehari-hari sehingga tidak cukup dianalisa menggunakan media 2D (media gambar).

3. Perbedaan hasil belajar siswa yang menggunakan media video pembelajaran dengan menggunakan media gambar yang terdapat dibuku paket

Pada proses pembelajaran kelas eksperimen siswa lebih aktif dalam pembelajaran, sehingga suasana di dalam kelas menjadi hidup dan menyenangkan. Guru hanya sebagai fasilitator dalam proses pembelajaran dikarenakan adanya variasi media yang digunakan berupa media video pembelajaran. Penelitian yang dilakukan Ade 
Sopian (2014) membandingkan hasil belajar IPS menggunakan media video dengan media gambar pada siswa SMK Depok, ditemukan bahwa terdapat perbedaan yang signifikan antara siswa yang diajar menggunakan media video dengan siswa yang diajar menggunakan media gambar. Menurut penelitian tersebut hasil belajar IPS, siswa yang diajar menggunakan media video lebih tinggi dibandingkan mengunakan media gambar. Hal serupa juga dilakukan Sugiyono dan Dwi Widjanarko (2017) perbandingan hasil belajar siswa menggunakan media gambar dengan menggunakan media video pada praktik sistem pengisian. Dalam penelitian tersebut, menemukan perbedaan hasil belajar yang signifikan. Kelompok eksperimen menggunakan media video yang semula 62,15 meningkat menjadi 83,59 dan pada kelompok kontrol menggunakan media gambar yang semula 62,30 meningkat menjadi 73,35. Berdasarkan penelitian tersebut pembelajaran menggunakan media video dinilai lebih efektif dalam meningkatkan hasil belajar.

Pada proses pembelajaran kelas kontrol, siswa kurang berperan aktif dalam pembelajaran karena guru hanya menggunakan media gambar yang terdapat dibuku paket. Guru hanya terfokus pada penyampaian materi menggunakan metode konvensional (ceramah). Dionysius Oktavian Andi Pratikno (2017) melakukan penelitian yang membandingkan hasil belajar menggunakan media video dengan metode konvensional pada siswa SD Sleman. Dalam penelitian tersebut pembelajaran dengan cara kovensional terkesan monoton dan tidak ada inovasi baru sehingga membuat hasil belajar kurang maksimal. Hal tersebut sejalan dengan penelitian Buyung Iman Taka (2016) yang menyatakan bahwa pembelajaran secara konvensional hanya terpusat pada siswa yang duduk di kursi depan. Keterbatasan pembelajaran konvensioanl yang menggunakan media gambar, tidak dapat menjangkau penglihatan siswa yang duduk di kursi belakang sehingga siswa tidak memiliki daya tarik terhadap pelajaran yang sedang dijelaskan guru.

Dalam penelitian ini, hasil belajar siswa pada kelas eksperimen memperoleh nilai ratarata 62,83. Hasil ini termasuk dalam kategori hasil belajar yang rendah. Sedangkan hasil belajar siswa pada kelas kontrol memperoleh nilai rata-rata 53,66. Hasil ini termasuk dalam kategori hasil belajar yang sangat rendah. Pengkategorian secara kualitatif skor hasil belajar siswa ini mengacu pada Depdiknas tentang interpretasi kategori nilai hasil belajar.

4. Efektivitas penggunaan media video pembelajaran

Untuk mengetahui sebarapa besar efektivitas media video pembelajaran yang sudah dilaksanakan dalam penelitian maka alat yang digunakan dalam menganalisis adalah dengan Effect size. Effect size bertujuan untuk mengukur besarnya korelasi atau perbedaan, atau efek dari suatu variabel pada variabel lain.

Berdasarkan hasil perhitungan, diperoleh nilai effect size sebesar 0,8 dengan kategori tinggi (berdasarkan kriteria interpretasi nilai cohen). Cohen (1988) memberikan kriteria nilai effect size (d) yaitu jika $0<\mathrm{d} \leq 0,2$ (efek kecil), $0,2<\mathrm{d} \leq 0,5$ (efek sedang), $0,5<\mathrm{d} \leq$ 0,8 (efek besar), dan $\mathrm{d}>0,8$ (efek sangat besar). Jika nilai effect size besar, maka mengindikasikan besarnya perbedaan ratarata antar kelompok. Jika nilai effect size sedang, maka mengindikasikan perbedaan rata-rata antar kelompok tidak besar dan tidak juga kecil.

Jika nilai effect size tersebut dikonversikan kedalam tabel kurva normal dari tabel O-Z, maka diperoleh luas daerah sebesar 0,2881. Hal ini menunjukkan dengan menggunakan media video pada pembelajaran geografi memberikan pengaruh sebesar $28,81 \%$ terhadap hasil belajar siswa pada materi ketahanan pangan, bahan industri dan energi terbarukan kelas XI IPS SMAN 1 Rasau Jaya.

\section{SIMPULAN DAN SARAN Simpulan}

Berdasarkan hasil penelitian yang telah dilakukan pada kelas XI IPS Sekolah Menengah Atas Negeri 1 Rasau Jaya dapat disimpulkan :

Berdasarkan hasil tes akhir siswa diketahui hasil belajar pada materi ketahanan pangan, energi, dan industri menggunakan media video pembelajaran terdapat 4 siswa yang mencapai KKM.

Berdasarkan hasil tes akhir siswa diketahui hasil belajar pada materi ketahanan 
pangan, energi, dan industri menggunakan media gambar yang terdapat dibuku paket tidak ada siswa yang mendapat nilai diatas KKM.

Berdasarkan hasil pengujian hipotesis pada kelas eksperimen yang menggunakan media video dan kelas kontrol yang menggunakan media gambar yang terdapat di buku paket diketahui bahwa $t_{\text {hitung }}>\mathrm{t}_{\text {tabel. }}(3,074>2,048)$ dengan nilai $0,003<0,05$ yang artinya terdapat perbedaan hasil belajar siswa pada materi ketahanan pangan, bahan industri, dan energi terbarukan kelas XI IPS.

Berdasarkan hasil uji effect size diperoleh ES sebesar 0,8 dengan kriteria tergolong tinggi. Maka dapat dikatakan bahwa penggunaan media video pembelajaran memberikan efektivitas yang tinggi terhadap hasil belajar siswa pada materi ketahanan pangan, energi dan industri kelas XI IPS.

\section{Saran}

Setelah penelitian dilakukan, terdapat beberapa temuan sebagai saran dalam proses pembelajaran geografi di sekolah menegah atas. Adapun saran dalam penelitian ini yang dapat penulis sampaikan sebagai berikut :

Penggunaan media video pembelajaran dapat digunakan sebagai alternatif media pembelajaran dalam upaya mempengaruhihasil belajar siswa pada kognitif menjadi lebih baik. Sehingga pada penelitian selanjutnya dapat menggunakan media video pembelajaran pada pokok bahasan lain.

Hendaknya guru dalam menggunakan media video pembelajaran sebaiknya memperhatikan beberapa hal yang dapat mempengaruhi kelancaran proses belajar mengajar seperti waktu pembelajaran yang harus disesuaikan dengan proses pembelajaran, banyaknya materi yang akan diajarkan serta jumlah siswa yang berada di dalam kelas dan perlengkapan media sebelum pembelajaran.

Bagi peneliti selanjutnya yang akan mengkaji penelitian ini lebih lanjut sebaiknya memperhatikan kelemahan atau keterbatasan media video, yaitu menyesuaikan jam pelajaran (waktu), materi yang akan disampaikan (pembuatan video), perlengkapan sebelum pembelajaran (alat-alat penunjang media). Agar peneliti tidak mengalami kesulitan dalam pengkajian lebih dalam mengenai penelitian seperti ini dan dapat melakukan penelitian yang lebih baik.

\section{DAFTAR RUJUKAN}

Ade S. (2014). Perbandingan Hasil Belajar IPS Siswa dengan Menggunakan Media Video Versus Media Gambar. http://lib.unnes.ac.id/33531/1/140141525 3_Optimized.pdf).

Ahmadi R. (2016). Pengantar Pendidikan Asas \& Filsafat Pendidikan. Yogyakarta: ArRuzz Media

Arsyad A. (2014). Media Pembelajaran. Jakarta: PT Raja Grafindo Persada

Becker, A L. (2000). Effect Size (ES). https://www.uv.es/ friasnav/EffectSizeBe cker.pdf.

Gusti, A J., \& Lawita, F N. (2020). An Application of Generative Learning Models To Improve Students Learning Outcomes Of Geography At X-IPS 3 Class SMA Negeri 1 Pekanbaru In Academic Year 2019/2020. Sumatra Journal of Disaster, Geography and Geography Education. 4 (1): 1-2.

Hamdani. (2011) Strategi Belajar Mengajar. Bandung: CV Pustaka Setia

Musfiqqon. (2012). Metode Penelitian Pendidikan. Jakarta: Prestasi Pustaka

Panua, Y E. (2019). Teaching and Learning Methods in Geography Promoting Sustainability. Education Sciences. http://aisteel2019.confpoint.org/kfz/files/a isteel_2019_mardimpu_sihombing_hqpr0 3 cvth.pdf.

Rahmat T. (2015). Metodologi Penelitian Kuantitaf. Bandung: Papas Sinar Sinanti

Sari, P A., \& Ananda S. (2018). The Development of Internet-Based Economic Learning Media using Moodle Approach. International Journal of Active Learning. 3 (2): 2 .

Slameto. (2015). Belajar dan Faktor-faktor yang Memengaruhinya. Jakarta: Rineka Cipta

Sugiyono. (2012). Metode Penelitian Kuantitatif, Kualitatif, dan $R \& D$. Bandung: Alfabeta . (2017). Metode Penelitian Kuantitatif, Kualitatif, dan $R \& D$. Bandung: Alfabeta, $\mathrm{CV}$

Sugiyono., \& Dwi W. (2017). Perbandingan Hasil Belajar Siswa Menggunakan Media Gambar dengan Menggunakan Media Video Pada Praktik Sistem Pengisian (The Comparison of Student Learning Outcomes Using Images Media With Using Video Media In Filling System 
Practices).

http://repository.uinjkt.ac.id/dspace/bitstr eam/123456789/26178/3/ADE\%20\%20S OPIAN-FITK.pdf.

Taka, B I. (2016). Efektifitas Penggunaan Media Video Terhadap Hasil Belajar Siswa pada Kompetensi Memahami dan Memelihara Sistem Starter Reduksi. https://journal.unnes.ac.id/sju/index.php/e dugeo/article/view/23590.

Woro, M P. (2019). Efektivitas Penggunaan Media Audio Visual dengan Media Gambar Terhadap Hasil Belajar IPS Siswa SDN Segugus Cakra Kota Semarang (Studi Komparasi). http://repository.usu.ac.id/bitstream/1234 56789/61801/1/Appendix.pdf 